\title{
PENGALAMAN DALAM PELAKSANAAN KLINIK BERHENTI MEROKOK DI KOTA DENPASAR
}

\section{EXPERIENCE IN IMPLEMENTING THE SMOKING CESSATION CLINIC IN DENPASAR}

\author{
Diah Prihatiningsih ${ }^{1}$, Ika Setya Purwanti ${ }^{2}$, Ni Luh Putu Devhy ${ }^{3}$ \\ ${ }^{1}$ Program Studi S1 Ilmu Keperawatan, STIKes Wira Medika Bali \\ ${ }^{2}$ Program Studi D3 Rekam Medik dan Informasi Kesehatan, STIKes Wira Medika Bali \\ ${ }^{3}$ Program Studi D3 Rekam Medik dan Informasi Kesehatan, STIKes Wira Medika Bali
}

\begin{abstract}
ABSTRAK
Salah satu kebiasaan yang lazim dilakukan oleh dua dari tiga orang laki laki dewasa di Indonesia adalah kebiasaan merokok, namun perilaku ini sangat potensial menimbulkan penyakit-penyakit kronis. Pemerintah Indonesia telah melakukan berbagai upaya untuk menurunkan jumlah perokok di Indonesia. Salah satu upaya yang dilakukan adalah dengan mendirikan Klinik Berhenti Merokok (KBM) di fasilitas pelayanan kesehatan dasar maupun rujukan. Penelitian ini menggunakan metode penelitian kualitatif dengan pendekatan fenomenologi deskriptif. Penelitian ini dilakukan di 4 Klinik Berhenti Merokok yang ada di Denpasar yaitu Puskesmas I Denpasar Utara, Puskesmas I Denpasar Barat, Puskesmas I Denpasar Selatan, Puskesmas I Denpasar Timur. Berdasarkan wawancara dan observasi yang dilakukan dari 4 responden/partisipan didapatkan 3 tema yang menunjukkan pengalaman pemegang program klinik berhenti merokok di kota Denpasar yaitu pelaksanaan Klinik Berhenti Merokok, hambatan selama pelaksanaan Klinik Berhenti Merokok dan saran untuk perbaikan pelaksaan klinik berhenti merokok. Partisipan mempersepsikan pemahamannya terhadap pelaksanaan klinik berhenti merokok sebagai sarana untuk menjaring perokok yang datang ke puskesmas untuk beerobat di poliklinik yang lain kemudian diberi informasi tentang adanya program berhenti merokok. Dalam program ini diberikan konseling mengenai bahaya rokok agar mereka mau berhenti untuk merokok. Partisipan mempersepsikan pemahamannya terhadap hambatan pelaksanaan klinik berhenti merokok adalah kurang nya masyarakat yang mau untuk datang ke klinik berhenti merokok. Partisipan mempersepsikan pemahamannya terhadap hambatan pelaksanaan klinik berhenti merokok adalah mensosialisasikan adanya klinik berhenti merokok. Serta menjaring pasien perokok yang berobat ke poli lain agar mau berkunjung ke klinik berhenti merokok.
\end{abstract}

Kata Kunci : Merokok, Klinik Berhenti Merokok,

\section{ABSTRACT}

One habit that is commonly practiced by two out of three adult men in Indonesia is smoking, but this behaviour has the potential to cause chronic diseases. The Indonesian government has made various efforts to reduce the number of smokers in Indonesia. One of the efforts is to establish a Smoking Cessation Clinic in primary and referral health care facilities. 
DOI: https://doi.org/10.36376/bmj.v6i2

This study uses qualitative research methods with descriptive phenomenological approach. This research was conducted in 4 smoking cessation clinics in Denpasar; Puskesmas I Denpasar Utara, Puskesmas I Denpasar Barat, Puskesmas I Denpasar Selatan, and Puskesmas I Denpasar Timur. Based on interviews and observations conducted by 4 respondents/participants, 3 big themes were founded, they were experience of the smoking cessation program in Denpasar, obstacles during the implementation of the smoking cessation clinic and suggestions for improving the implementation of the smoking cessation clinic. Participants perceive their understanding of the implementation of the smoking cessation clinic as a means to attract smokers who come to the Puskesmas for medical treatment and are then given information about the existence of a smoking cessation program. In this program counselling is given about the dangers of smoking so they want to stop smoking. The difficulties pf implementating the smoking cessation clinic is the lack of people who are willing to come to the smoking cessation clinic, a need to socialize the existence of a smoking cessation clinic and redirecting those who went to other polyclinics to visit the smoking cessation clinic.

Keywords : Smoke, Smoking Cessation Clinic

\begin{tabular}{ll}
\hline Alamat Korespondensi & $\begin{array}{l}\text { : STIKes Wira Medika Bali Jln. Kecak No. 9A Gatot Subroto Timur } \\
\text { Denpasar } \\
\text { : diahciprik@gmail.com }\end{array}$ \\
\hline
\end{tabular}

\section{PENDAHULUAN}

Salah satu kebiasaan yang lazim dilakukan oleh dua dari tiga orang laki laki dewasa di Indonesia adalah kebiasaan merokok, namun perilaku ini sangat potensial menimbulkan penyakit-penyakit kronis antara lain kanker paru, bronchitis kronis, penyakit paru, jantung coroner, peningkatan kolesterol darah, berat badan bayi lahir rendah (BBLR) pada ibu perokok, keguguran dan bayi lahir mati. Sangat mudah dijumpai orang yang merokok dalam kehidupan sehari hari, baik itu di dalam rumah, di berbagai pertemuan, maupun juga di fasilitas umum yang seharusnya bebas dari asap rokok (Firzawati, 2015).

Banyak perokok yang ingin berhenti merokok hanya dengan mengandalkan motivasi diri sendiri dan lingkungan serta berbagai metode alternatif, ternyata gagal dan kembali merokok. Sulitnya berhenti merokok ini ditunjukkan oleh sebuah survei berskala internasional yang dilakukan Pfizer Inc. yaitu studi SUPPORT (Smoking Understanding People's Perceptions, Opinions and Reactions to Tobacco) pada tahun 2006. Hasil survei ini memperlihatkan bahwa $56 \%$ responden yang sedang dalam proses berhenti merokok berpendapat bahwa berhenti merokok adalah hal tersulit yang pernah dilakukan. Kebanyakan perokok percaya bahwa keberhasilan dalam upaya berhenti merokok terutama terletak pada kuatnya keinginan dari diri perokok itu sendiri. Hasil survei membuktikan bahwa keinginan kuat saja tidak cukup untuk berhenti merokok. Lebih dari setengah responden pernah mencoba untuk berhenti merokok setidaknya tiga kali dan $80 \%$ di antara yang gagal tersebut hanya mengandalkan keinginan yang kuat saja.

Pemerintah Indonesia telah melakukan berbagai upaya telah dilakukan untuk menurunkan jumlah perokok di Indonesia. Salah satu upaya yang dilakukan adalah dengan mendirikan Klinik Berhenti Merokok (KBM) di fasilitas pelayanan 
DOI: https://doi.org/10.36376/bmj.v6i2

kesehatan dasar maupun rujukan. Klinik ini berupaya membantu para perokok aktif untuk berhenti merokok berdasarkan tahap demi tahap yang disertai dengan konseling dari tenaga terlatih (Susanti, 2015).

Penelitian yang dilakukan Lamapaha (2014) mendapatkan hasil bahwa evaluasi kinerja klinik berhenti merokok di kampus yang difasilitasi Dinas Pendidikan Provinsi Jawa tengah tidak berjalan dengan baik karena tidak semua klinik berhenti merokok memiliki sumber daya yang lengkap baik dari sumber daya manusia, sarana dan fasilitas, alat dan bahan, metode, dan dana yang dapat menunjang kinerja klinik berhenti merokok untuk mencapai tujuan yang diharapkan.

Sejalan dengan hasil penelitian yang dilakukan Susanti (2015) menunjukkan sebanyak 33,3\% dari masyarakat yang mempunyai motivasi baik untuk menggunakan KBM. Hambatan penyelenggaraan KBM disebabkan oleh faktorfaktor : 1) Pembiayaan, 2) Sarana dan Prasarana, 3) Insentif, 4) Koordinasi, 5) Tugas pokok dan fungsi petugas, 6) Perencanaan, 7) Sosialisasi, 8) Dukungan Pemerintah Daerah, dan 9) Evaluasi.

Penelitian yang dilakukan Alvitia (2017) mengenai efektivitas pelaksanaan klinik berhenti merokok di kota Solok 2017 menunjukkan hasil klinik berhenti merokok di kota Solok belum berjalan efektif, dilihat dari jumlah kunjungannya tidak mengalami peningkatan. Kurangnya sosialisasi tentang klinik berhenti merokok membuat masyarakat belum banyak mengetahui tentang hal tersebut. Konseling yang diberikan tidak sesuai petunjuk teknis, dll.

Berdasarkan dari berbagai penelitian yang sudah ada sebelumnya membuat peneliti tertarik untuk mengetahui pengalaman petugas kesehatan dalam pelaksanaan klinik berhenti merokok di kota Denpasar.

\section{METODE PENELITIAN}

Penelitian ini menggunakan metode penelitian kualitatif dengan pendekatan fenomenologi deskriptif. Penelitian ini dilakukan di 4 Klinik Berhenti Merokok yang ada di Denpasar yaitu Puskesmas I Denpasar Utara, Puskesmas I Denpasar Barat, Puskesmas I Denpasar Selatan, Puskesmas I Denpasar Timur. Penelitian ini dilakukan pada bulan Februari - Maret 2018. Partisipan pada penelitian ini adalah petugas yang menjalankan tugasnya di Klinik Berhenti Merokok. Variabel bebas pada penelitian ini adalah pelaksana klinik berhenti merokok sedangkan variable terikat pada penelitian ini adalah kegiatan pelaksanaan klinik berhenti merokok. Adapun instrument penelitian pada penelitian ini adalah peneliti itu sendiri sebagai instrument utama, pedoman wawancara, catatan lapangan, dan alat perekam.

Teknik pengumpulan data pada penelitian ini adalah dengan wawancara dengan mengekplorasi perasaan, persepsi, dan pemikiran partisipan (Rachmawati, 2014). Sumber data yang digunakan adalah sumber data primer. Sumber data primer merupakan sumber data yang langsung memberikan data kepada pengumpul data (Sugiyono, 2012). Prosedur penelitian dan pengumpulan data dilakukan melalui beberapa tahapan yaitu prosedur administrasi dan prosedur teknis. Analisis data pada penelitian kualitatif ini dilakukan dalam du acara yaitu melakukan abstraksi data dan melakukan interpretasi. 


\section{Hasil Penelitian}

\section{HASIL DAN DISKUSI}

Pada penelitian ini mengambil sampel sebanyak 4 orang pemegang program Klinik Berhenti Merokok di Puskesmas yang ada di kota Denpasar. Berdasarkan wawancara dan observasi yang dilakukan dari 4 responden/partisipan didapatkan 3 tema yang menunjukkan pengalaman pemegang program klinik berhenti merokok di kota Denpasar yaitu pelaksanaan Klinik Berhenti Merokok, hambatan selama pelaksanaan Klinik Berhenti Merokok dan saran untuk perbaikan pelaksaan klinik berhenti merokok. Pada bagian ini juga menjelaskan mengenai tema tema yang teridentifikasi pada penelitian ini. Pembahasan dari masing masing tema akan diperkuat oleh konsep teori dan hasil penelitian terkait yang dilakukan peneliti sebelumnya.

\section{Diskusi Hasil}

1. Pelaksanaan Klinik Berhenti Merokok Partisipan mempersepsikan pemahamannya terhadap pelaksanaan Klinik Berhenti Merokok seperti dijelaskan sebagai berikut :

"Pertama ini setelah pergub tentang Kawasan Tanpa Rokok. Kemudian ada Perwali. Dari perwali otomatis banyak perokok yang tertarik untuk berhenti merokok. "

"Mulai tahun 2014. Sebenarnya awalnya susah. Kalau orang mau berhenti merokok itu gak segampang itu dia mau. Untuk mencari yang mau datang ke klinik berhenti merokok susah"

"Awalnya pelatihan dulu petugasnya. Kemudian kita sosialisasi, kita lakukan penyuluhan bahaya rokok dan mengajak berhenti merokok. Kita akan memberikan bantuan kepada perokok yang ingin berhenti merokok" "Selain melaksanakan pelayanan di Klinik Berhenti Merokok kami juga tetap melaksanakan tupoksi lain di puskesmas"

Partisipan mempersepsikan pemahamannya terhadap pelaksanaan klinik berhenti merokok sebagai sarana untuk menjaring perokok yang datang ke puskesmas untuk beerobat di poliklinik yang lain kemudian diberi informasi tentang adanya program berhenti merokok. Dalam program ini diberikan konseling mengenai bahaya rokok agar mereka mau berhenti untuk merokok. Pada awal pendirian Klinik Berhenti Merokok ini adalah setelah terbentuknya peraturan daerah kota Denpasar nomor 7 tahun 2013 mengenai Kawasan Tanpa Merokok.

Fungsi sebagai konselor Klinik Berhenti Merokok adalah sebagai sumber informasi mengenai bahaya rokok dan memberikan motivasi yang bersifat persuasif kepada perokok mengenai dampak kebiasaan merokok mereka.

Dari hasil wawancara diketahui juga bahwa petugas pelaksana Klinik Berhenti Merokok mempunyai tugas rangkap yang lain di puskesmas sehingga sibuk juga melayani pasien lain. Hal tersebut sejalan dengan penelitian Susanti (2015) yang menyatakan bahwa tugas pokok dan fungsi pelaksana di KBM yang tidak jelas dan tidak sesuai dalam pelaksanaanya karena tugas rangkap pekerjaan sehingga hanya mengandalkan satu orang personil. 
2. Hambatan Selama Pelaksanaan Klinik Berhenti Merokok

Partisipan mempersepsikan pemahamannya terhadap hambatan pelaksanaan Klinik Berhenti Merokok seperti dijelaskan sebagai berikut :

"Pasien yang terjaring dari poli kemudian dibawa kesini. Awalnya mau di konseling tetapi kemudian untuk diminta datang kembali melanjutkan konselingnya tidak mau. Susah follow up. Sehingga kita tidak tahu mereka beneran berhenti atau tidak"

"Pasien yang tidak mau dikonseling karena merasa nyaman untuk merokok. Mereka tidak tahu ada klinik berhenti merokok"

"Klinik Berhenti Merokok ada di lantai atas sedangkan poli ada di lantai bawah. Jadi banyak yang berkunjung ke puskesmas tidak tahu kalau ada Klinik ini. Kami petugas pun juga merangkap dengan tugas yang lain”

Partisipan mempersepsikan pemahamannya terhadap hambatan pelaksanaan klinik berhenti merokok adalah kurang nya masyarakat yang mau untuk datang ke klinik berhenti merokok. Hal ini sejalan dengan penelitian Devhy (2019) yang menyatakan bahwa sebanyak 90,9\% responden tidak mengetahui tentang klinik berhenti merokok. Sosialisai yang masih kurang akan menyebabkan sedikitnya orang yang datang untuk mengunjungi klinik berhenti merokok.

Menurut Susanti (2015) kurnagnya sosialisasi tentang keberadaan Klinik Berhenti Merokok juga merupakan hambatan dalam pelaksanaan KBM. Kurangnya sosialisasi ini menyebabkan masyarakat tidak banyak yang mengetahui keberadaan KBM di puskesmas. Sosialisasi bias dilakukan kapan dan dimana saja. Media promosi kesehatan dapat digunakan sebagai alat untuk melaksanakan sosialisasi karena mempermudah penyampaian informasi ke sasaran.

Menurut penelitian Idayani (2018) menyatakan bahwa pemanfaatan klinik berhenti merokok sangat rendah. Pencarian pasien berdasarkan kunjungan yang ke poli umum, kurangnya fasilitas penunjang, dan pelayana hanya berfokus pada pemberian informasi. Menurut Devhy (2019) potensi pemanfaataan klinik berhenti merokok sangat tinggi, terbukti dari responden ada sebanyak $75,8 \%$ yang ingin menyarankan keluarganya untuk berkunjung ke klinik berhenti merokok dan mengikuti program berhenti merokok.

Motivasi masyarakat untuk menggunakanan Klinik Berhenti Merokok masih kurang, hanya sebesar 33,3\% dari masyarakat yang mempunyai motivasi baik untuk menggunakan Klinik Berhenti Merokok (Susanti, 2015). Walaupun hanya sebagian kecil yang mempunyai motivasi baik, keberadaan klinik berhenti merokok masih diperlukan untuk memfasilitasi masyarakat yang membutuhkan

3. Saran Perbaikan Pelaksanaan Klinik Berhenti Merokok

Partisipan mempersepsikan pemahamannya terhadap saran pelaksanaan Klinik Berhenti Merokok seperti dijelaskan sebagai berikut :

"Harus ada komitmen bersama semua orang, baik dari pemerintah dan semuanya. Komitmennya harus kuat dari masyarakat itu harus memang betul-betul gimana sih orang itu harus berhenti merokok. Semua harus sadar kalau merokok itu tidak bagus. Itu saya secara pribadi. Kalau orang yang ga 
DOI: https://doi.org/10.36376/bmj.v6i2

berkomitmen paling hanya bilang tutup aja pabrik rokok. Bener sih tapi kan kalau ga ada yang beli rugi."

Partisipan mempersepsikan pemahamannya terhadap hambatan pelaksanaan klinik berhenti merokok adalah mensosialisasikan adanya klinik berhenti merokok. Serta menjaring pasien perokok yang berobat ke poli lain agar mau berkunjung ke klinik berhenti merokok. Hal tersebut sesuai dengan penelitian Devhy (2019) bahwa potensi pemanfaatan klinik berhenti merokok cukup besar. Hal tersebut dapat dilihat dari kemauan responden untuk mengajak keluarga nya berkunjung ke klinik berhenti merokok.

Dengan meningkatkan sosialisasi keberadaan klinik berhenti merokok, dan mengupayakan letak klinik berhenti merokok di tempat yang strategis maka diharapkan kunjungan ke klinik berhenti merokok akan meningkat. Penggunaan media promosi kesehatan juga dapat digunakan untuk melakukan sosialisasi. Media yang dapat digunakan berupa media cetak seperti leaflet, poster, brosur yang disebarkan ke masyarakat.

\section{SIMPULAN DAN SARAN}

Penelitian ini dilakukan dengan melakukan wawancara terhadap pemegang program klinik berhenti merokok dalam melaksanakan pelayanan di klinik berhenti merokok. Berdasarkan hasil analisa dan pembahasan dapat disimpulkan bahwa dalam pelaksanaan klinik berhenti merokok sudah berjalan dengan baik dan hambatan pelaksanaan klinik berhenti merokok adalah kurangnya sosialisasi sehingga keinginan dari perokok untuk datang ke klinik berhenti merokok masih rendah.

Adapun saran penelitian ini adalah untuk melanjutkan penelitian lebih mendalam mengenai faktor-faktor penyebab kurangnya pelaksanaan klinik berhenti merokok dan melakukan kolaborasi Klinik Berhenti Merokok dengan poliklinik dan program kesehatan lainnya agar pemanfaatan klinik berhenti merokok meningkat

\section{DAFTAR PUSTAKA}

Devhy, dkk. (2019). Gambaran Kesadaran Perokok untuk Mengikuti Konseling di Klinik Berhenti Merokok di Kota Denpasar. Jurnal Kesehatan Indonesia, Volume IX, Nomer 3, Juli 2019

Firzawati. (2015). Faktor Upaya Berhenti Merokok pada Perokok Aktif Umur 15 Tahun Keatas di Indonesia. Disestasi. Universitas Indonesia

Idayani, Sri, dkk. (2018). Utilization of Smoking Cessation Clinic at Public Health Centre 1 North Denpasar : A Qualitative Study. Public Health and Preventitive Medicine Archive volume 6 nomer 2: 148-153

Lamapaha, Helena Elvy. (2014). Evaluasi Kinerja Klinik Berhenti Merokok di Kota Semarang tahun 2014. Universitas Dian Nuswantoro Semarang

Susanti, Dewi. (2015) Evaluasi Hambatan Penyelenggaraan Klinik Berhenti Merokok di Kabupaten Purwakarta. http://repository.unpad.ac.id/20481/ Tesis. Universitas Padjajaran 